\title{
Breakup Condition of a Liquid Bubble Exposed to Airstreams
}

\author{
○正吉日照彦（管京大）岡澤 弘之（需京大院） \\ 井上 神寿 (帝京大)
}

Teruhiko YOSHIDA, Teikyo University, 1-1 Toyosatodai, Utsunomiya-City

Hiroyuki OKAZAWA, Teikyo University Graduate School, 1-1 Toyosatodai, Utsunomiya-City

Yoshihisa INOUE, Teikyo University, 1-1 Toyosatodai, Utsunomiya-City

\section{1. 緒論}

液体を微粒化すると表面皘が著しく增大するため， 燃焼や熱交換を促進させることができる，液体在液澓 ではなく，液滴内部に気体を含ませた液泡にすれば， 表面積がさらに堌加するので，微粒化效果もより高く なると考えられる，渡泡を燃焼や，高温液体の気流に よる冷却などに使用することを考えた場合，どのよう な条件で液泡はよ゙のような分裂をするのかを調べるこ 上は重要である，本研究では，液泡が気流にさらされ た場合，液泡を構成する液体の物性が変形や分裂にど のような影響老及ぼすのかを調べる。

\section{2. 主要記号および次元}

$D_{b}$ : 液泡徍（液泡の外径 $=$ 直徍） $\mathrm{L}$

$D_{e q}$ : 液泡の相当值径 $=D_{b} D_{i} /\left(D_{b}+D_{i}\right) \quad \mathrm{L}$

$D_{i}$ : 液泡の问徍 $\mathrm{L}$

$F_{b}$ : 滶泡の生成頻度 $\mathrm{T}^{-1}$

$Q_{a}:$ 空気流量 $\mathrm{L}^{3} \mathrm{~T}^{-3}$

$Q_{l}:$ 液体流量 $\mathrm{L}^{3} \mathrm{~T}^{-1}$

Re:レイノルズ数 $=u_{a} D_{b} / v_{a}$

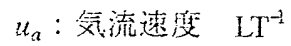

$W e_{a}:$ 液泡のウェ-バ数 $=\rho_{a} u_{a i}^{2} D_{e q} /(2 \sigma)$

$\delta$ : 液膜厚さ $=\left(D_{b}-D_{i}\right) / 2 \quad \mathrm{~L}$

$v_{a}:$ 気流の動粼性倸数 $\mathrm{L}^{2} \mathrm{~T}^{-1}$

$\rho_{a}:$ 気流の密度 $\mathrm{ML}^{-3}$

$\sigma:$ 液体の表面張力 $\mathrm{MT}^{-2}$

\section{3. 実験装置および実験条件}

図 1 に実験装犆系統図を示す，風胴は蝠 $60 \mathrm{~mm}$ 火高 さ $150 \mathrm{~mm}$ の長方形断面定持つ, 長さ $500 \mathrm{~mm}$ の然気 昅引型水平風胴である。液泡生成に使用する液体は 50\% (体積)エ夕ノール水溶液, 50\% (体積)グリセりン水 溶液である、気流速度は $0-40 \mathrm{~m} / \mathrm{s}$ だ，液泡が気流に
さらされて変形，分裂ずる様子はストロボスコープを 用いて観察し，またカメラで写窴撮影する。

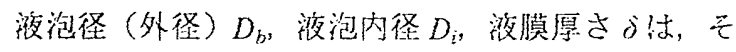
れぞれ式(1)，(2)，(3)で求められる。

$$
\begin{aligned}
& D_{b}=\left\{6\left(Q_{a}+Q_{l}\right) /\left(\pi F_{b}\right)\right\}^{1 / 3} \\
& D_{i}=\left\{6 Q_{a} /\left(\pi F_{b}\right)\right\}^{1 / 3} \\
& \delta=\left(D_{b}-D_{i}\right) / 2
\end{aligned}
$$

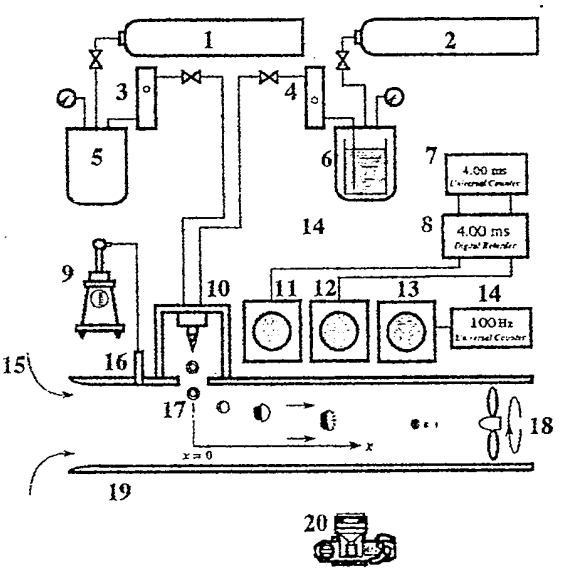

1, 2. compressed air, 3. air flow meter, 4. water flow meter, 5. air tank, 6. liquid task, 7. universal counter 8. digital retarder, 9. Bctz manomcter, 10. nozzle, 11 , 12. 13. stroboscope, 14. uniwersal counter, 15. air stream, 16. static pressure tap, 17. liquid bubbies, is. fan, 19. wind tumel, 20. cancra,

Fig.l Experimental apparatus for liquid bubble

\section{4.実験結果および考察}

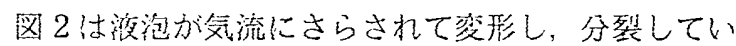
く㥞子在示す，渡泡径は $5.93 \mathrm{~mm}$ で，生成頻度 $120 \mathrm{pps}$ (particle per second) の均一粒径腹泡である，(a) 気流 が流れていない場合である。(b) 液泡は後背部がふく らむものの，分裂はしない（c）液泡は分裂したり， しなかったりするようになる。このような分裂は遥移 分裂と呵ばれる。(d) 液泡化確実に分裂するようにな る. 液泡定確実に分裂へ上導く最低の気流速度は臨界 気流速度と㖕げれ，この条件での分裂は臨界分裂と呼 


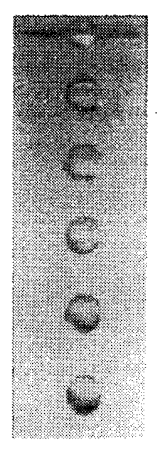

(a) $u_{a}=0$

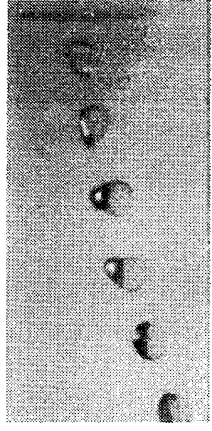

(b) $u_{a}=4.03 \mathrm{~m} / \mathrm{s}$

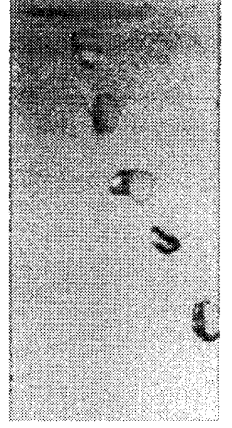

(c) $u_{a}=6.98 \mathrm{~m} / \mathrm{s}$

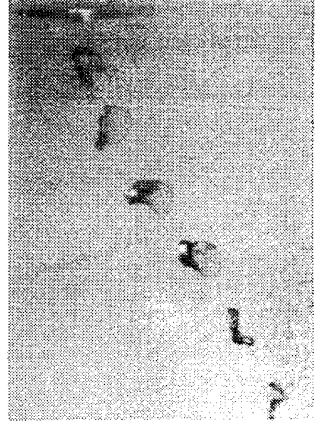

(d) $u_{0}=8.06 \mathrm{~m} / \mathrm{s}$

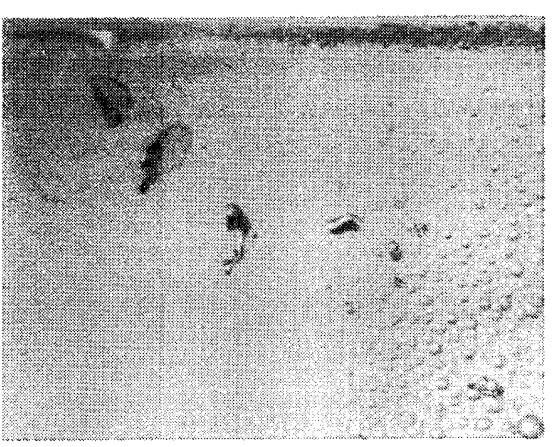

(e) $u_{a}=9.87 \mathrm{~m} / \mathrm{s}$

$50 \%$ (vol.) Ethanol water solution, $D_{b}=5.93 \mathrm{~mm}, D_{i}=5.42 \mathrm{~mm}, \delta=0.26 \mathrm{~mm}, F_{b}=120 \mathrm{pps}, D_{e q}=2.83 \mathrm{~mm}$

Fig. 2 Breakup liquid bubbles exposed to airstreams

ばれる。（e）液泡の液膜が破れて中に入っていた空気 が抜け，残った液体が液塊（液滴）となり，それが気 流によってさらに分裂する。このような分裂は二次分 裂と呼ばれる。

図 3 は $50 \%$ (体積) エ夕ノール水溶液について, 液 泡径によって遷移分裂, 臨界分裂, 二次分裂が起こる 気流速度がじのように変化していくのかを示す、いず れの分裂に対しても液泡径が小さくなるにつれて，分 裂を引き起こす気流速度は大きくなる．臨界分裂が起 こる液泡径と気流速度（臨界気流速度）の関係は式(4) で表される。

$$
u a_{\text {crit }}=36.1 D_{b}^{-0.836}, \quad\left(3 \mathrm{~mm}<D_{b}<9 \mathrm{~mm}\right)
$$

図 4 は 50\%（体積）グリセリン水溶液について，液 泡径によって遷移分裂，臨界分裂，二次分裂が起こる 気流速度がどのように変化していくのふを示す。臨界 分裂が起こる液泡径と臨界気流速度り関係は式(5)で 表される。

$$
u a_{\text {crit }}=36.4 D_{b}^{-0.815}, \quad\left(3 \mathrm{~mm}<D_{b}<10 \mathrm{~mm}\right)
$$

遷移分裂永始まる気流速度は，液泡径が同じであれ ば,エタノ一ル水溶液わらなる液泡の場合の方が高い。 臨界分裂が始まる気流速度は，ほぼ同じである。エ夕 ノ一ル液泡では液泡が分裂してできた液塊が臨界気流 速度より少し高い気流にさらされると二次分裂を起こ すが，グリセリン液泡では，かなり気流速度を高くし 代、上二次分裂在起こさない。

\section{5.まとめ}

液体の物性によって，液泡の分裂形態には違いが見 ら礼，遷移分裂，臨界分裂，二次分裂を生じる気流速 度と液泡径の関倸も変わってくる。

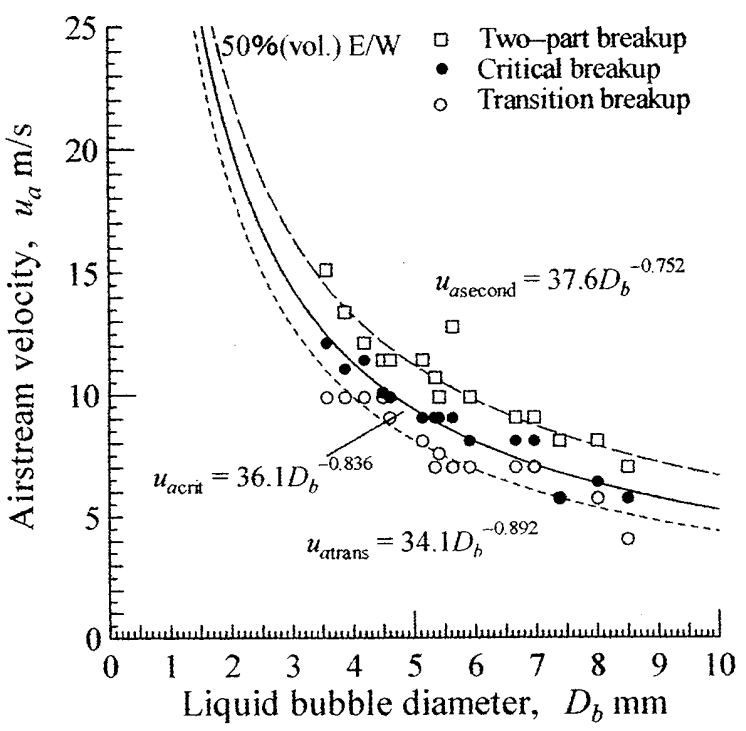

Fig. 3 Relationship between liquid bubble diameter and airstream velocity

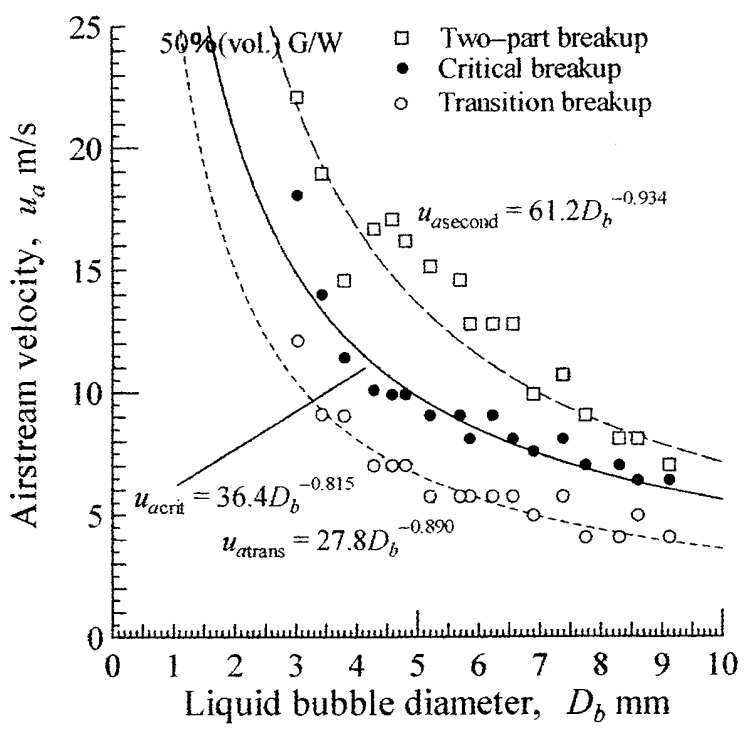

Fig. 4 Relationship between liquid bubble diameter and airstream velocity 